his ideas on heat, gases, vapours, and such matters, but also his thoughts on conduct and life. Thus he writes, on various occasions:

"Régler le matin l'emploi de sa journée et réfléchir le soir à ce qu'on a fait."

"La promptitude des résolutions s'accorde le plus souvent avec leur justesse."

"Parler peu de ce qu'on sait et point du tout de ce qu'on ne sait pas."

"La vie est un passage assez court. Je suis à la moitié du chemin. J'achèverai le reste comme je pourrai."

"Les lois de la guerre, dit-on ; comme si la guerre n'était pas la destruction de toutes les lois."

Carnot had had an uncle, a magistrate who, stricken with apoplexy in court, had exclaimed, "Vous allez voir comment on passe courageusement de la vie à la mort". It was in that spirit that Carnot had faced the long illness which led to his own death.

\title{
Obituary
}

\section{Mr. George Barrow}

$\mathrm{M}$ R. GEORGE BARROW, who died at his home in London on July 23, at the age of seventyeight years, was a well-known geologist, who served for thirty-nine years on the Geological Survey of Great Britain. His earliest work was carried on in the north of England, especially in north Yorkshire. Afterwards he was transferred to Scotland, where he spent many years in surveying the southern Highlands, especially Aberdeenshire, Kincardineshire, and Forfarshire. This work brought him into prominence and placed him in the first rank of British authorities on metamorphic rocks and the tectonics of ancient crystalline provinces.

In 1900, Barrow returned to England and was entrusted with the mapping of parts of Cornwall and Devon, including Bodmin Moor and the southern flanks of Dartmoor. On his promotion to District Geologist in 1909, Barrow took charge of work in the London district, and interested himself greatly in economic geological problems, such as water supply and underground railways. He retired from the Geological Survey in 1915, and thereafter devoted his energies, to a considerable extent, to the local administration of the district in which he lived.

In his official work, Barrow was responsible for contributions to a large number of maps and memoirs published by the Geological Survey. Of these we may mention Cheadle (1903), Whitby (1882), Braemar (1912), Blair Atholl (1905), Scilly Isles (1906), Tavistock (1911), Bodmin (1909), Dartmoor (1912). This list might be considerably extended, but is sufficient to indicate the variety of his work. He was an active member of the Geological Society, the Mineralogical Society, and the Geologists' Association, served on their councils, and published papers in their transactions. In 1912 he received the Bolitho Gold Medal from the Royal Geological Society of Cornwall, and in 1913 the Murchison Medal from the Geological Society of London.

Barrow was a remarkably original field geologist, with a very acute eye for surface features and their relations to geological structure and history. His work on the high-level platforms of the west of England and the Pliocene features of the country around London is a good example of this. He was exceedingly painstaking and thorough, and was one of the first in Britain to perceive the importance of microscopic investigation of the older crystalline rocks. Working under the influence and tuition of Allan Dick, he applied these methods to Scottish Highland problems and obtained results of great value. In this he was really a pioneer. He was endowed with constructive imagination and a wonderful intuition, which led him often to arrive at conclusions very rapidly and in a manner which even his colleagues had some difficulty in understanding. Yet often these hypotheses, which seemed at first mere guesses, turned out to be sound. Consequently he had a very stimulating personality, and his conversation on geological topics was very inspiring, especially to younger men who had not his wide experience in the field. A genial companion and a generous opponent, he knew how to enjoy life, and retained his wide outlook, his courage, and his enthusiasm to the end of his days.

\section{J. S. F.}

\section{Mr. R. Staples-Browne, M.B.E.}

Richard Staples-Browne, of Butler's Court, Alvescot, Oxfordshire, who died on June 5, was born in 1881, and from Rugby School went up to Emmanuel College, Cambridge, taking his degree by the Natural Sciences Tripos of 1902. He then commenced the medical courses, but the endocrine trouble which afflicted him throughout life called for a voyage round the world before he passed his second M.B. examination in 1906. About this time he came under the influence of William Bateson and relinquished medical study for biology, always his chief interest.

Staples-Browne's experimental work on inheritance in pigeons is among the best pioneer studies engendered by the rediscovery of Mendel's papers ; he showed that Darwin's inquiry into the origin of the domesticated races of pigeons was unnecessarily complicated, and that his results are capable of simple explanation on Mendelian lines. Sex-linked. heredity in doves was demonstrated by StaplesBrowne just after this important condition had been discovered in poultry, and he may be said to have laid the foundation of our genetical knowledge of pigeons. During the War he joined up with the Medical Corps of the New Zealand Expeditionary Force, and, with the rank of captain, he did four years' service in its clerical and statistical branches in England, for which he was awarded the M.B.E. 